\title{
JUDUL PENELITIAN
}

\section{ANALISIS FAKTOR - FAKTOR YANG MEMPENGARUHI MINAT NASABAH MENABUNG DI PT. BANK RAKYAT INDONESIA (Persero) CABANG MAROS}

\author{
Syarifah Ihdah Syahdhani \\ syarifahihda@gmail.com
}

Institut Bisnis \& Keuangan Nitro Makassar

\begin{abstract}
ABSTRAK
Penelitian berjudul "Analisis Faktor - faktor Yang Mempengaruhi Minat Nasabah Menabung Di PT. Bank Rakyat Indonesia (Persero) Cabang Maros" Penelitian ini bertujuan untuk mengetahui dan menganalisis Faktor - faktor yang mempengaruhi minat nasabah menabung di Bank Rakyat Indonesia (Persero), Tbk. Cabang Maros.

Penelitian ini menggunakan metode pengumpulan data dengan cara membagikan kuesioner. Teknik pengambilan sampel menggunakan rumus slovin. Metode analisis data yang digunakan yaitu analisis deskriptif, uji instrumen, analisis regresi linier berganda, uji asumsi klasik, dan uji hipotesis.
\end{abstract}

\section{Kata Kunci : Minat Nasabah, Menabung}

\section{PENDAHULUAN}

Peranan bank sangatlah penting bagi pereknomian suatu negara dalam hal mendukung pembangunan, karena pembangunan ekonomi di suatu negara sangat bergantung kepada dinamika perkembangan dan kontribusi nyata dari sektor perbankan. Pertumbuhan dalam perkembangan bank terutama bank konvensional bisa dilihat dari semakin banyaknya jaringan, aset, banyaknya produk - produk yang ditawarkan dan banyaknya Dana Pihak Ketiga (DPK) yang dihimpun dari masyarakat.

PT. Bank Rakyat Indonesia (Persero) Tbk, di singkat dengan BRI merupakan salah satu bank milik pemerintah terbesar di Indonesia. BRI memiliki banyak unit bisnis yang tersebar di seluruh Indonesia dan beberapa diluar negeri. Sebagai Bank, BRI senantiasa berupaya memfokuskan diri pada kebutuhan keuangan konsumen yang tidak berhenti pada peningkatan nasabah semata.

Menurut Taswan (2010:7) Bank adalah sebuah lembaga atau perusaan yang aktifitasnya menghimpun dana berupa giro, deposito, tabungan dan simpanan yang lain dari pihak yang kelebihan dana (surplus spending unit) kemudian menempatkanya kembali kepada masyarakat yang membutuhkan dana (deficit spending unit) melalui penjualan jasa keuangan yang pada giliranya dapat meningkatkan kesejahteraan rakyat banyak. 
Menabung dalam ilmu ekonomi adalah salah satu tindakan yang mempersiapkan tentang perencanaan-perencanaan masa yang akan datang serta sekaligus sebagai persiapan diri untuk menghadapi halhal yang tidak diinginkan dikemudian hari. Menurut Kamus Besar Bahasa Indonesia (2005), menabung merupakan sebuah kata kerja yang memiliki arti yaitu menyimpan uang (di celengan, pos, bank, dan sebagainya). Secara luas menabung dapat diartikan sebagai suatu kegiatan menyisihkan sebagian pendapatannya untuk dikumpulkan sebagai cadangan pada masa yang akan datang.

Menabung, itu berarti kita sudah memiliki persiapan untuk masa depan kita, menabung juga membantu kita untuk memiliki modal (capital) ketika kita ingin melakukan suatu usaha sehingga kegiatan ekonomi kita berlangsung dengan produktif, dan tabungan yang kita miliki tentunya kita bisa gunakan untuk perputaran modal demi kesejahteraan kita dan keluarga. (Indi, 2019).

Terkait dengan anjuran untuk menabung, maka diperlukan suatu lembaga keuangan yang dapat di percaya. Oleh karena itu salah satu solusi yang ditawarkan sebagai tempat menabung adalah menabung di Bank Rakyat Indonesia (BRI).

\section{TINJAUAN PUSTAKA}

a. Pengertian Bank

Bank adalah suatu industri yang bergerak dibidang kepercayaan yang dalam hal ini adalah sebagai media perantara keuangan (financial intermediary) antara debitur dan kreditur dana. (Santoso, 1999 : 1). Dengan demikian fungsi bank mencakup tiga hal pokok, yaitu: sebagai pengumpul dana, sebagai penjamin kredit antara debitur dan kreditur. Sebagai penanggung resiko interest rate trasformasi dana, dari tingkat suku bunga rendah ke tingkat suku bunga tinggi. Pengertian di atas merupakan pengertian umum yang menggambarkan fungsi bank secara pokok sebagai pengumpul dan penyalur dana.Dengan demikian ada tiga bentuk tugas (operasi) yang dilakukan oleh bank yaitu :

1) Operasi perkreditan secara aktif, ialah tugas dalam rangka menciptakan atau memberikan kredit yang dilaksanakan oleh bank.

2) Operasi perkreditan pasif, ialah tugas menerima simpanan atau dana yang dipercaya oleh pihak ketiga. Dana yang dipercayakan tersebut dapat berupa Giro, Tabungan, Deposito berjangka, Sertifikat Deposito, pinjaman dari bank sentral, penarikan dana-dana dari pihak ketiga dengan agunan jaminan efekefek.

3) Usaha bank sebagai perantara dalam perkreditan. Sebagai perantara maka bank memberikan jasa jasa seperti :

a) Pengiriman uang/transfer yang merupakan salah satu pelayanan bank kepada masyarakat dimana bank bersedia melaksanakan amanat nasabah untuk mengirimkan uang baik dalam rupiah maupun dalam valuta asing 
dan ditujukan kepada pihak lain (perusahaan, lembaga atau perorangan) ditempat lain baik dalam negeri maupun diluar negeri.

b) Bertindak melakukan guachet yaitu hanya mengurus pendaftaran saja daripada emisi.

c) Menyelenggarakan emisi bagi perusahaan yang hendak memperbesar modalnya. Bank memberikan jasanya sebagai penerima dalam penjualan saham- saham atau obligasi perusahaan.

d) Menjamin penempatan efek-efek. Bank menjamin akan menanggung resiko mengenai efek-efek (saham, obligasi) yang tidak terjual dengan harga sedikit di bawah emisi sehingga dari selisih itu dapat ditutup biaya emisi dan termasuk semua biaya resiko bank.

e) Memberikan jaminan bank (bank garansi). Bank garansi yang diberikan bank kepada perorangan, perusahaan maupun badan lembaga dengan menyatakan bahwa bank akan memenuhi kewajiban-kewajiban dari pihak yang dijamin tersebut kepada pihak lainnya (penerima jaminan) apabila suatu waktu yang telah ditentukan, pihak yang dijamin tidak dapat memenuhi kewajibannya.

f) Menyewakan tempat penyimpanan barang-barang berharga.

g) Memberikan penerangan.Bank dapat memberikan keterangan mengenai perusahaan kepada perorangan baik di dalam negeri maupun di luar negeri perihal bonafiditas ataupun watak seorang pengusaha.

h) Menginkasokan wesel-wesel atau tagihan-tagihan lainnya.

Dari uraian diatas dapatlah dimengerti bahwa aktivitas bank itu sangatlah luas sekali dalam lalu lintas perekonomian.

b. Fungsi dan Usaha Bank Umum

Bank umum adalah suatu badan usaha yang kegiatan utamanya menerima simpanan dari masyarakat dan atau pihak lainnya, kemudian mengalokasikannya kembali untuk memperoleh keuntungan serta menyediakan jasa jasa dalam lalu lintas pembayaran. (Subagyo, 2000:44). Dari pengertian tersebut, bank menjalankan fungsi yang berkaitan dengan pengumpulan dana, pengalokasian dana serta penyediaan jasa jasa dalam lalu lintas pembayaran.

Sedangkan fungsi khusus bank umum adalah :

1) Fungsi Pengumpul Dana

Yang dimaksud di sini ialah dana masyarakat yang disimpan di bank terutama dalam bentuk giro, deposito, dan tabungan. Ketiga unsur dana inilah yang merupakan sumber-sumber dana utama bank, selain sumber yang berasal dari modal sendiri bank (terdiri dari modal penyertaan dan laba yang tidak dibagikan).

2) Fungsi Pemberian Kredit 
Dana yang dikumpulkan melalui penerimaan giro, deposito, dan tabungan oleh bank harus segera dijalankan, sebab terhadap dana yang dikumpulkan tersebut bank terkena beban biaya berupa jasa giro, bunga deposito, bunga tabungan, dan biaya operasional. Alternatif pemakaian dana yang menguntungkan pihak bank dan tidak banyak mengganggu likuiditas bank adalah pemberian kredit jangka pendek kepada pihak ketiga.

3) Fungsi Penanaman Dana

Yang dimaksud investasi dalam manajemen bank adalah investasi finansial yaitu penanaman dana dalam bentuk surat-surat berharga, baik surat tanda pemilikan (saham) ataupun surat tanda utang (obligasi, surat wesel, SBI).

4) Fungsi Penciptaan Uang

Dari sudut ekonomi makro atau ekonomi moneter, fungsi penciptaan uang dipandang sebagai fungsi paling pokok bank umum dalam perekonomian.

5) Fungsi Pembayaran

Fungsi pembayaran ini tidak hanya dilakukan melalui cek atau bilyet giro melainkan juga melalui surat wesel, transfer, uang baik melalui surat ataupun telegram.

6) Fungsi Transfer

Dalam prakteknya kegiatan transfer ini dicampur dengan unsur-unsur kegiatan utama lainnya. Misalnya saja menerima dan membayarkan kembali uang dalam rekening koran, menjalankan perintah untuk pemindahan uang, menerima pembayaran dari tagihan atas kertas berharga dan melakukan perhitungan dengan atau antara pihak ketiga, semua ini dikatagorikan ke dalam produk jasa perbankan yang biasa disebut jasa trust.

c. Pengertian, Jenis dan Manfaat Tabungan

Simpanan adalah dana yang dipercayakan oleh masyarakat kepada bank dalam bentuk giro, deposito berjangka, tabungan, atau bentuk lainnya yang dipersamakan dengan itu (UU No. 7 tahun 1992). Sedangkan tabungan adalah simpanan yang penarikannya hanya dapat dilakukan menurut syarat tertentu yang telah disepakati, tetapi tidak dapat ditarik dengan cek atau alat yang dapat dipersamakan dengan itu (UU Np. 7 Tahun 1992). Dengan menabung maka secara tidak langsung bank akan mendapatkan dana, dan dana tersebut oleh bank nantinya akan dioperasikan. Sebagai imbalannya maka nasabah mendapatkan bunga atas tabungan tersebut dan dikembangkan dalam rangka kelancaran pembangunan secara keseluruhan serta peningkatan kesejahteraan masyarakat pada khususnya.

Pengertian konsep pemasaran adalah sebuah falsafah bisnis yang menyatakan bahwa pemuasan kebutuhan konsumen merupakan syarat ekonomi dan sosial bagi kelangsungan hidup perusahaan (Basu Swastha dan Irawan, 1999 : 10). Sebagai falsafah bisnis, konsep pemasaran bertujuan untuk memberikan kepuasan 
terhadap keinginan dan kebutuhan konsumen atau berorientasi pada konsumen (consumer oriented). Hal ini secara mendasar jelas berbeda dengan falsafah bisnis terdahulu yang berorientasi pada produk (produk concept) dan penjualan (financial consept).

Price diartikan sebagai kebijaksanaan penetapan harga produk bank (terutama kredit) yang ditawarkan kepada masyarakat. Kebijaksanaan penetapan harga produk bank jauh lebih komplek di bandingkan penetapan harga untuk produk manufaktur. Dalam memantapkan harga produk,sebagian besar bank mempergunakan satu dari ketiga metode berikut atau kombinasinya.(Sutojo : $2001: 138)$.

d. Perilaku Konsumen

Menurut Engel (2011:3) (di kutip dalam Daga, 2021) perilaku konsumen sebagai tindakan yang langsung terlibat dalam mendapatkan, mengkonsumsi, dan menghabiskan produk dan jasa termasuk proses keputusan yang menghabiskan dan yang menyusuli tindakan ini. Oleh karena itu besar kecilnya suatu pasar tergantung pada jumlah orang yang menunjukkan kebutuhan, mempunyai sumber daya yang menarik bagi orang lain dan mampu menyediakan sumber daya tersebut untuk memperoleh apa yang mereka inginkan.

Ada tiga variabel dalam mempelajari perilaku konsumen, yaitu variabel stimulus, variabel respons dan variabel intervening.

1) Variabel Stimulus

Variabel stimulus adalah yang berada diluar diri individu (faktor eksternal) yang sangat berpengaruh dalam proses pembelian contohnya; merk dan jenis barang, Man, pramuniaga.

2) Variabel respon

Variabel respon merupakan hasil aktivitas individu sebagai reaksi dan variabel stimulus. Variabel respon sangat tergantung pada faktor individu dan kekuatan stimulus. Contohnya : keputusan membeli barang, perubahan sikap terhadap suatu produk, pemberi penilaian terhadap barang.

3) Variabel intervening

Variabel intervening adalah variabel antara stimulus clan respon, Variabel ini merupakan faktor internal individu, termasuk motif untuk membeli, sikap terhadap satu peristiwa, dan persepsi terhadap suatu barang. Peranan variabel intervening adalah untuk memodifikasi respon.

e. Faktor - faktor yang Mempengaruhi Minat Nasabah untuk Menabung

Tentunya setiap bank ingin mengumpulkan dana dari masyarakat sebanyak mungkin. Usaha-usaha yang dilakukan oleh bank yang satu dengan bank yang lainnya, tentunya berbeda- beda. Dalam hal ini ada beberapa faktor yang mempengaruhi pengambilan keputusan menabung. Faktor-faktor ini dibagi 
menjadi faktor ektern (faktor yang tidak bisa dikontrol oleh bank) dan faktor intern (faktor yang dapat dikontrol oleh bank)

1) Faktor-faktor ektern
a) Faktor kebudayaan
b) Kelas social
c) Kelompok referensi
d) Keluarga

2) Faktor-faktor intern
a) Tingkat suku bunga
b) Status Bank
c) Lokasi
d) Pelayanan yang diberikan
e) Jasa

\section{f. Minat}

Kamus Besar Bahasa Indonesia (KBBI) sebagaimana dikutip oleh Moeliono (1999: 225) memaknai minat sebagai sebuah kecenderungan hati yang tinggi terhadap suatu gairah atau keinginan. Sementara itu, Muhaimin (1994: 4) memaknainya sebagai kecenderungan seseorang untuk menentukan pilihan aktifitas dan tergantung dari kondisi individu sehingga bersifat labil. Hal senada juga diungkapkan oleh Poerwadarminta (2006: 769). Sedangkan secara istilah, minat dimaknai sebagai perangkat mental yang terdiri dari suatu campuran dari perasaan, harapan, pendirian, prasangka, atau kecenderungan lain yang mengarahkan individu kepada suatu pilihan tertentu tanpa ada suatu paksaan dari pihak lain. (Mappiare, 1997: 62, Shaleh dan Muhbib, 2004: 263, Sudarsono, 1993: 156, Muhbin Syah, 1999: 136, dan Slameto, 2010: 180).

Minat tidak berdiri sendiri melainkan erat kaitannya dengan faktor intern maupun ekstern. Faktor intern yang memengaruhi minat di antaranya umur, berat badan, jenis kelamin, pengalaman dan sebagainya, sedangkan faktor eksternnya di antaranya lingkungan keluarga, sekolah, dan sebagainya. Crow, sebagaimana kutip Saleh (2004: 265-267) mengemukakan tiga faktor yang memunculkan minat, pertama; dorongan dari dalam individu. Contohnya dorongan untuk makan akan membangkitkan minat untuk bekerja atau mencari penghasilan. Kedua; motif sosial, misalnya dorongan untuk mendapat penghargaan dari lingkungan tempat tinggal membangkitkan minat untuk berkreasi. Ketiga; emosional. Keinginan atas sesuatu membangkitkan minat untuk bertindak.

\section{METODE PENELITIAN}


Penelitian ini di lakukan di PT. Bank Rakyat Indonesia (Persero) kantor cabang Maros Jl. Jend. Sudirman, Alliritengae, Kec. Turikale, Kabupaten Maros. Waktu penelitian dibutuhkan kurang lebih 1 bulan.

\section{A. DEFINISI OPERASIONAL VARIABEL}

Definisi operasional variabel yang digunakan dalam penelitian ini meliputi :

1. Faktor Keluarga

Menurut Effendy (2005), keluarga adalah unit terkecil dari masyarakat yang terdiri atas kepala keluarga dan beberapa orang yang berkumpul dan tinggal di suatu tempat di bawah suatu atap dalam keadaan saling ketergantungan.

2. Kelompok Referensi

Menurut Sumarwan (2011:305) kelompok referensi adalah seorang individu atau sekelompok orang yang secara nyata mempengaruhi perilaku seseorang.

3. Tingkat suku bunga

Tingkat suku bunga menurut Boediono (2014:76) adalah "harga dari penggunaan dana investasi (loanable funds).

4. Status Bank

Menurut Kamus Besar Bahasa Indonesia (KBBI) kata status bermakna keadaan atau kedudukan (orang,badan, dsb.) dalam hubungannya dengan masyarakat di sekelilingnya; keadaan atau kedudukan orang atau sesuatu di mata hukum.

5. Kualitas Pelayanan

Menurut Kotler menyatakan bahwa kualitas harus dimulai dari kebutuhan pelanggan dan berakhir pada persepsi pelanggan. Pihak yang menilai suatu jasa itu berkualitas atau tidak adalah pelanggan karena merekalah yang mengkonsumsi jasa perusahaan. Untuk itu suatu perusahaan jasa yang ingin tetap unggul bersaing harus dapat menyediakan jasa yang mempunyai kalian tinggi secara berkenimbangan.

6. Lokasi bank

menurut Kasmir (2009:129) Lokasi yaitu tempat melayani konsumen, dapat pula diartikan sebagai tempat untuk memajangkan barang- barang dagangannya.

\section{B. ANALISIS DATA}

1. Analisis Deskriptif 
Menurut Sugiyono (2013:5), yaitu suatu cara atau prosedur yang digunakan untuk melakukan penelitian, sehingga mampu menjawab rumusan masalah dan tujuan penelitian.

2. Uji Instrumen

a. Uji Validitas

Uji validitas digunakan untuk mengukur sah atau valid tidaknya suatu kuesioner. Alat ukur yang digunakan dalam pengujian validitas adalah daftar pertanyaan yang telah di isi oleh responden dan akan di uji hasilnya guna menunjukkan valid tidaknya suatu data. Bila valid, ketetapan pengukuran data akan semakin tetap alat ukur tersebut. Dikatakan valid jika nilai signifikan $\leq 0,05$.

b. Uji Reabilitas

Menurut Sugiyono (2012:119) uji reabilitas digunakan untuk mengetahui keandalan kuesioner yang digunakan. Reabilitas adalah indeks yang menunjukkan sejauh mana alat ukur dapat dipercaya atau diandalkan. Dikatakan reabil jika nilai Cronbach Alpha $\geq 0,60$.

3. Analisis Regresi Linier Berganda

Analisis yang digunakan dalam penelitian ini adalah dengan menggunkan model persamaan regresi linier berganda, yang digunakan untuk mengetahui seberapa besar pengaruh keluarga (X1), kelompok referensi (X2), tingkat suku bunga (X3), status bank (X4), pelayanan (X5) dan Lokasi (X6) terhadap minat nasabah menabung (Y) pada PT. Bank Rakyat Indonesia (Persero), Tbk. Cabang Maros.

$$
\mathrm{Y}=\mathrm{a}+\mathrm{b} 1 \mathrm{X} 1+\mathrm{b} 2 \mathrm{X} 2+\mathrm{b3X3}+\mathrm{b4X4}+\mathrm{b5X5}+\mathrm{b} 6 \mathrm{X6}
$$

Keterangan :

Y

a

0 (harga konstan).

$\mathrm{B} 1, \mathrm{~b} 2, \mathrm{~b} 3, \mathrm{~b} 4, \mathrm{~b} 5, \mathrm{~b} 6=$ angka arah atau koefisien regresi, dimana jika (+) arah garis naik dan bila (-) maka arah garis turun.

$$
\begin{array}{ll}
\mathrm{X} 1 & =\text { Keluarga } \\
\mathrm{X} 2 & =\text { Kelompok regresi }
\end{array}
$$


X3

$\mathrm{X} 4$

X5

X6
= Tingkat Suku Bunga

$=$ Status Bank

$=$ Pelayanan

$=$ Lokasi

4. Uji Asumsi Klasik

a. Uji Normalitas Data

Uji normalitas data adalah hal yang lazim dilakukan sebelum sebuah metode statistik.Uji normalitas merupakan salah satu bagian dari uji persyaratan analisis data biasa disebut asumsi klasisk.Tujuan uji normalitas adalah untuk mengetahui apakah distribusi normal, yakni distribusi data yang mempunyai pola seperti distribusi normal.

Dalam penelitian ini peneliti menggunkan analisa grafik, dengan metode kita dapat dapat melihat grafik histogram dan normal probability plot. Deteksinya dengan melihat penyebaran data (titik) pada sumbu diagonal dari grafik. Data pengambilan keputusan dari analisa grafik tersebut adalah

1) Jika data menyebar di sekitar garis diagonal dan mengikuti arah garis diagonal, maka regresi memenuhi asumsi normalitas.

2) Jika data menyebar jauh dari garis diagonal atau tidak mengikuti arah garis diagonal, maka model regresi tidak memenuhi asumsi normalitas.

b. Uji Multikolinearitas

Uji multikolinearitas bertujuan untuk menguji apakah model regresi ditemukan adanya korelasi antar variabel bebas/independen (Ghozali, 2013:105).Untuk mengetahui ada atau tidaknya multikoliearitas, mengacu pada nilai yang dipakai untuk menunjukkan adanya multikolonieritas nilai tolerance $>0,10$ atau sama dengan nilai VIF < 10. Ghozali (2013:106).

5. Uji Hipotesis

a. Uji Parsial (uji t)

Uji ini pada dasarnya menunjukkan seberapa jauh pengaruh suatu variabel independen secara individual (parsial) dalam menerangkan variasi variabel dependen. (Suliyanto;2011) langkah yang digunakan dalam menguji hipotesis 
ini adalah dengan menentukan level of significane-nya. Level of significane yang digunakan adalah sebesar 5\% atau $(\grave{\alpha})=0.05$. Jika sign $\mathrm{t}>0.05$ maka $\mathrm{Ha}$ ditolak namun jika sig $\mathrm{t}<0.05$ maka Ha diterima dan berarti terdapat pengaruh yang signifikan antara variabel independen dengan variabel dependen (suliyanto;2011).

b. Uji Simultan (Uji F)

Uji ini dilakukan untuk menunjukkan apakah semua variabel independen atau bebas yang dimasukkan dalam model mempunyai pengaruh secara bersama-sama terhadap variabel dependen atau terikat. Ghozali (2013:98).

Untuk menguji hipotesis ini digunakan statistik $\mathrm{F}$ dengan kriteria pengambilan keputusan sebagai berikut:

1) Quick lokk : bila nilai $\mathrm{F}$ lebih besar daripada 4 maka $\mathrm{H} 0$ ditolak pada derajat keyakinan 5\%. Dengan kata lain kita menerima hipotesis alternative yang menyatakan bahwa semua variabel independen secara serentak dengan signifikan mempengaruhi variabel dependen.

2) Membagikan nilai $F$ hasil perhitungan dengan nilai $F$ menurut table. Bila nilai $F$ hitung lebih besar daripada nilai $F$ maka HOditolak dan menerima HA.

\section{6. $\quad \mathrm{Uji} \mathrm{R}^{2}$ (Koefisien determinasi)}

Koefisien determinasi $\left(\mathrm{R}^{2}\right)$ pada intinya adalah mengukur seberapa jauh kemampuan model dalam menerangkan variasi variabel dependen.Nilai $\mathrm{R}^{2}$ adalah diantara nol dan satu. Jika nilai $\mathrm{R}^{2}$ berkisar hamper satu, berarti semakin kuat kemampuan variabel independen dalam menjelaskan variabel dependen dan sebaliknya jika nilai $\mathrm{R}^{2}$ semakin mendekati angka nol, berarti semakin lemah kemampuan variabel independen dalam menjelaskan variabel dependen. Suliyanto (2011).

\section{KESIMPULAN}

Menabung dalam ilmu ekonomi adalah salah satu tindakan yang mempersiapkan tentang perencanaan-perencanaan masa yang akan datang serta sekaligus sebagai persiapan diri untuk menghadapi halhal yang tidak diinginkan dikemudian hari. Terkait dengan anjuran untuk menabung, maka diperlukan suatu lembaga keuangan yang dapat di 
percaya. Secara istilah, minat dimaknai sebagai perangkat mental yang terdiri dari suatu campuran dari perasaan, harapan, pendirian, prasangka, atau kecenderungan lain yang mengarahkan individu kepada suatu pilihan tertentu tanpa ada suatu paksaan dari pihak lain. Oleh karena itu salah satu solusi yang ditawarkan sebagai tempat menabung adalah menabung di Bank Rakyat Indonesia (BRI).

Variabel - variabel yang digunakan dalam penelitian ini adalah :

1. Faktor Keluarga

2. Kelompok Referensi

3. Tingkat suku bunga

4. Status Bank

5. Kualitas Pelayanan

6. Lokasi bank

\section{DAFTAR PUSTAKA}

Daga, R. (2016). ANALISIS FAKTOR-FAKTOR YANG MEMPENGARUHI NASABAH MENDEPOSITKAN DANANYA MELALUI TABUNGAN BRITAMA JUNIO PADA PT. BANK RAKYAT INDONESIA (Persero) Tbk. KANTOR CABANG TAMALANREA. AKMEN Jurnal Ilmiah, 13(2).

Kotler, Philip, 2005, Manajemen Pemasaran Analisis, Perencanaan, Implementasi dan Pengendalian, Terjemahan : Hendra Teguh dan Ronny Rusli Jilid I, Edisi Revisi, Prenhallindo, Jakarta.

Nazir, Moh, 2004, Metode Penelitian, Cetakan Ketiga, Ghalia Indonesia

Ni Made Ratnadi, 2003, Faktor-faktor Apa yang Mempengaruhi Nasabah Menabung di Bank-Bank Pemerintah di Mataram

Radford, K.J., 2004, Analisis Kepuasan Konsumen, Erlangga, Jakarta Santoso, Ruddy, Tri, 2004, Mengenal Dunia Perbankan, Cetakan Pertama, Andi Offset, Yogyakarta.

Widyono, Try. 2006. Aspek Hukum Operasional Transaksi Produk Perbankan di Indonesia. Bogor: Ghaila Indonesia 